
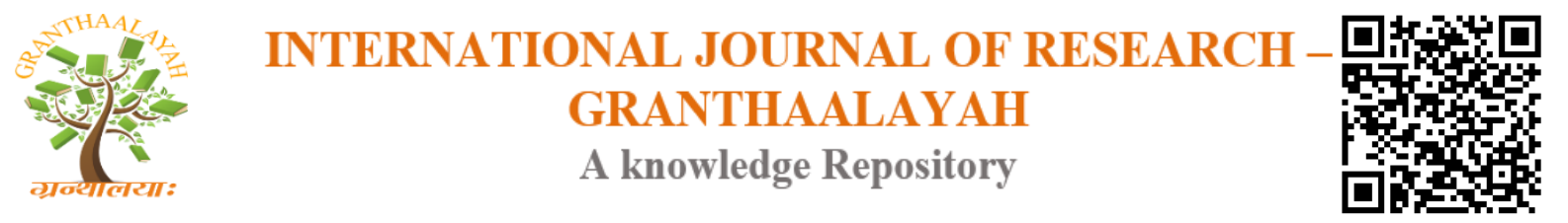

Science

\title{
EVOLUTION OF DIAGNOSTIC TECHNIQUES OF DEATH: AYURVEDA PERSPECTIVE AND MODERN TRENDS IN INDIA
}

\author{
Gopendra Chandra Kamal *1, Sourav Ballav ${ }^{2}$, Ashwini Kumar S Bharati ${ }^{3}$ \\ ${ }^{* 1,2}$ Final year PG Scholar, Department of Agada Tantra, SDM College of Ayurveda and \\ Hospital, Hassan, Karnataka, India \\ ${ }^{3}$ Professor, Department of Agada Tantra, SDM College of Ayurveda and Hospital, Hassan, \\ Karnataka, India
}

\begin{abstract}
Background: Death is the permanent and irreversible cessation of the tripod of life, viz. the brain, the heart and the lungs. However, there exist philosophical, religious and cultural differences in the concept of death. The diagnosis of death has medical and legal implications which have come a long way over the years and in the regions.

Method: The references available regarding the diagnostic techniques for declaring death in classical text were studied and compared with the available information in the contemporary medical literatures and published articles.

Result: A number of Ayurveda literatures such as Charaka Samhita, Sushruta Samhita, Astangahrdayam, Vishavaidyasarasamuchhaya, Vishavaidya jyotsnika etc. written in different era by authors from different region have put forward their techniques for diagnosing death which are mostly similar, simple and gross. With the advent of technology and the development of Modern medical sciences, the clincians in India have been following the western system mostly the one practiced in United Kingdom for diagnosing death. The focus has shifted the cardio-respiratory cessation to brain-stem death due to the development of artificial ventilator system and scope for organ transplantation. However, there is need for universal guidelines and much progress have been made regarding the same. Some of the governing laws in this regard in India are Transplantation of Organ Act (THO Act 1994, 2011, 2014) and THO Rules 1995.

Conclusion: Ayurveda criteria also focused on declaring death based on the cessation of the function of the three vital organs, although using different sets of techniques. Better, more specific and accurate techniques have evolved over the years.
\end{abstract}

Keywords: Death; Ayurveda; Visha; Thanatology.

Cite This Article: Gopendra Chandra Kamal, Sourav Ballav, and Ashwini Kumar S Bharati. (2018). "EVOLUTION OF DIAGNOSTIC TECHNIQUES OF DEATH: AYURVEDA PERSPECTIVE AND MODERN TRENDS IN INDIA.” International Journal of Research - Granthaalayah, 6(6), 109-118. https://doi.org/10.29121/granthaalayah.v6.i6.2018.1355. 


\section{Introduction}

There exists philosophical, religious, and cultural differences in the concept of death and ways it is defined making the discussions of the subject very complex. Advances in medicine and technology that have made it possible to support, repair, or failing organs. These developments challenge the commonly held notions of life and death. [1] Death is the permanent and irreversible cessation of the functions of the tripod of life, viz. brain, heart and lungs. [2] All death is diagnosed by confirming the irreversible loss of the capacity for consciousness combined with the irreversible loss of the capacity to breathe. The most appropriate set of criteria to use is determined by the circumstances in which the medical practitioner is called upon to diagnose death. [3] Diagnosis of death has significance with regards to consequences such as: no medical or legal requirement to provide resuscitation or ventilator; loss of personhood and individual rights and duties; the eligibility for organ donations and autopsy proceedings, executions of the decedent's' legal will, estate and property transfer; payment of life insurance; final disposition of body; religious and social ceremonies to mark the end of life. [4] It is highly desirable that the society proceed with the greatest caution and deliberation in proposing procedures that in any way threaten the traditional sanctity of the individual life. As a consequence the society will certainly move very slowly in developing formal arrangements for taking into account the interest of others in life and death decisions. [5] Over the years, various criteria and technologies have been used to diagnose death in different parts of the world. Ayurveda is ancient science of life and it has been the mainstream medical system in India until hundred years before. Agada Tantra is one amongst the eight branches of the Astanga Ayurveda. It deals with the toxicological aspects and hence diagnosis of death. Charaka Samhita, Sushruta Samhita, Astangahrdayam are the three major compendia of Ayurveda literature. The Ayurveda masters have expressed the techniques to diagnose death in these books. The criteria and techniques mentioned by these three masters from different ages and from different region are almost similar, which explains the universality of death. The techniques advised are: to check for permanent and irreversible loss of consciousness by applying tiksna nasya / anjana ( strong nasal drops/ collyrium), to check for circulatory failure by making incision over forehead, check for loss of tonicity by looking out for impressions on striking body parts with ropes or rods. Cessation of cardiorespiratory function has historically defined death. With the advent of cardiopulmonary resuscitation techniques, the cardiopulmonary definition of death lost its significance in favour of brain death. Question of death is important in resuscitation and organ donation. This article is based on the textual review of the major Ayurveda compendias (Charaka Samhita, Sushruta Samhita, Astangahridyam) and the available commentaries on these literatures. Relevant Scientific literatures and publications were referred to understand the concept of diagnosis of death and substantiate the Ayurveda approach for the same.

\section{Material and Methods}

\subsection{Charaka Samhita}

Charaka Samhita is considered to be most authentic thesaurus of various aspects of Ayurveda with special reference to fundamental principles of medicines. The compendia itself was compiled in three stages. Initially, it came up as "Agnivesa Tantra". Later Acharya (sage) Charaka redacted Agnivesa's work and propagated Ayurveda among mankind, sometime around $6^{\text {th }}$ century BC. Drdhbala is credited with the completion of the work as such and he belonged to Pancanadpura which is the modern-day Punjab [6] 
The imminent signs of death (Charaka Samhita Chikitsasthan 23/33-34) - if there is bluish discolouration of the lips, looseness of teeth, falling of hair, breaking of limbs, rigor mortis, absence of horripilations even after sprinkling cold water, non-formation of contusions on the body parts in reaction to blows and absence of bleeding from ulcers; the poisoned patients should be considered as dead and further treatment should be stopped [7]

\subsection{Sushruta Samhita}

Sushruta Samhita is the only text now available on Shalya Tantra (surgery) in Ayurveda. The compendia is the work of Acharya Sushruta, one of the disciple of Divodas Dhanwantari, king of Kasi (Varanasi). Acharya Nagarjuna completed the work and Acharya Dalhana wrote the commentary. This work dates back to 600 BC. [8]

Indications to stop further treatment (Sushruta Samhita kalpasthan 3/40-41) - when blood does not flow out on making incision with sharp instrument, if marks do not develop on the body parts when tied with creepers, if horripilations do not happen cold water sprinkled, when tongue has become white, hairs have fallen off, nose and throat have been broken, the site of the bite having swelling is blackish- reddish colour, whose lower jaw is stable(not moving); such patients should be rejected. [9]

\subsection{Astangahrdayam}

Astangahrdayam is the quintessence of the eight branches of Ayurveda and is one of the authoritative treatises on ancient medicine. It is the work of Acharya Bagbhatta. A similar treatise named Astangasamgraha is written by Bagbhatta of Sindhu region. However, there is difference of thoughts among the scholars regarding the authors of these two treatises. Some considers, both treatises to be the work of same person, while some are of the opinion that the works might of two authors with same name. The date of Bagbhatta has been presumed to be around 2 AD. [10] Techniques used to diagnose death (Astangahrdayam Uttarasthan 36/ 36-37) - those patients who do not regain consciousness by strong nasal medication, who do not bleed from the incision and who do not develop linear marks when hit by the baton are to be considered dead. [11]

\subsection{Vishavaidyasarasamuchhaya [12]}

Vishavaidyasarasamuchaya is a unique treatise which deals with Vishachikitsa (toxicology). The treatise is the work of Cherukulappurath Krishnan Namboodiri (1879-1966) written in Sanskrit language. The text is standard reference amongst the Vishavaidyas (physicians treating poison cases) in Kerala (India). The Mrtalakshana (signs of death) mentioned are: (1) Blood is not seen on incision made over the forehead with spike of the paddy seeds and if at all seen, it is blackish and very small in quantity. (2) Water is sprinkled and swept over by hand over the hairy part of the body, fails to produce horripilations. (3) The body of the patient does not sink when put into water. (4) Swelling is not produced when the thighs are beaten with a shaft. If still doubt arises, the body should be immersed in water and look out for bubbles. Immediate formation of lots of bubble indicates death, incase of absence of bubbles, observe for sometimes and if some bubbles forms, it should be concluded that the death has not occurred and should be tried with Nasya (insuffulation) and Anjana (collyrium) to bring back consciousness. 


\subsection{Vishavaidya Jyotsnika [13]}

Vishavaidya Jyotsnika is one of the most popular and most widely practiced book which catered to the needs of professional and emerging practitioners of Vishavaidya in Kerala. The book is originally written in Malayalam. It was published in 1958 by Government of His Highness, The Maharaj of Travancore.

Gatajeeva lakshana (signs of death) mentioned are the involuntary passage of urine and faeces, no bleeding even after incising the forehead, dark and composed body, wet hair and if they remain so for long, floating of body if immersed in water, appearance of no stuck marks if hit by a stick, anus, eyes and mouth if remain open, no movement of eyeballs. All these are confirmatory signs of death.

\subsection{Contemporary Thanatology [14]}

Thanatology is the scientific study of death in all aspects including its cause and phenomena. It also includes bodily changes that accompany death (post-mortem changes) and their medico-legal significance. There are three modes of death depending upon the system most obviously affected, irrespective of what the remote cause of death may be. These are coma, syncope and asphyxia. Death occurs in two stages- (1) somatic or systemic or clinical death (2) Molecular or cellular death. Somatic Death is complete and irreversible cessation of the function of brain and stoppage of the circulation and respiration. It precedes molecular death. Tissue and cells of body are alive and functioning. Muscles respond to thermal, electrical and chemical stimulus. It is confirmed by flat ECG and EEG and absent of breath sounds. It has resemblance with suspended animation, coma and hypothermia. Molecular death is the progressive disintegration of body tissues with death of individual tissues and cells. The confirmatory signs are Rigor Mortis, Algor Mortis, Postmortem staining, putrefaction.

The changes after death can be categorised as - immediate changes, early changes and late changes. The immediate changes after death are - (1) Irreversible cessation of the functions of the nervous system which is characterised by insensibility, and loss of both sensory and motor functions, loss of reflexes, no reflexes and no tonicity of the muscles and pupils are widely dilated. (2) Irreversible cessation of respiration is characterised by complete stoppage of respiration for more than four minutes. The stoppage of respiration is established by inspecting for any visible respiratory movements, absence of breath sounds on auscultation and also feather test, mirror test and Winslow's test. (3) Irreversible cessation of circulation is characterized by stoppage of heartbeat for more than five minutes. It is established by the absence of radial, brachial, femoral and carotid pulsations, absence of heart beat sound on auscultating over precordial area, flat line ECG recording and also some tests like I-card test, pressure test, diaphanous test, magnus test, cut and heat tests. Early changes after death - (1) Skin become pale, ash- white colour and loose loses elasticity. (2) Lips become brownish, dry and hard. (3) Muscles turn flaccid and loose tonicity. (4) Area in contact with ground becomes flat and blood from vessels is pressed out known as contact flattening. (5) Changes in Eyes are characterized by loss of corneal and pupillary reflex; dilated pupils with change in shape (it is circular during life); opacity and haziness in cornea; tache noire (two yellow triangles at either side of iris develops on sclera); Intraocular pressure becoming zero in 4-8 hour resulting into sunken eye ball; Retina- retinal vessels appearing segmented (Kevorkian 
sign) along with steady rise in values of vitreous potassium and hypoxanthine levels. (6) Algor Mortis -Temperature falls down after some hours as it tends to be equal to temperature of immediate environment. The curve of cooling is inverted ' $S$ ' Shaped. It is useful to determine time since death (Time since death $=$ normal rectal temperature - measured rectal temperature/ Rate of fall of temperature per hour). Average rate of fall of body temperature is $0.4-0.7 \mathrm{C}^{0}$. Body attains environmental temperature in 16-20 hour. (7) Livor Mortis - Also known as hypostasis, lucidity, cogitation, vibices, suggilation, cadaveric lividity, post-mortem staining. Post-mortem staining is bluish or purplish-red discolouration resulting from gravitational settling of blood in the toneless capillaries and venules of the dependent parts of the dead body. Sites are usually under-surface of skin and the superficial layers of the dermis. Upper portion of the body is pale. It develops in 1-2 hours as discoloured patches; patches coalesce in next two hours and process is completed in 5-6 hours. Fixation takes place in 8-12 hours and persists till putrefaction. It is absent in areas directly pressed on the ground (contact pallor) or areas with collar bands, waist bands, belts or wrinkles. (8) Rigor mortis- State of muscles in dead when they become stiff or rigid with some degree of shortening. ATP is required for the maintenance of actin-myosin complex, hence soft and supple muscle fibers. But after death, due to lack of ATP, muscle loose elasticity, softness and extensibility. Rigor mortis occurs in both voluntary and involuntary muscle. It commences in 1-2 hour, develops in 9-12 hour, persists for another 12 hour and takes 12 hour to pass away. Sequence as per Nysten's law is muscles of eye lid, jaw, facial muscles, neck, thorax, upper limb, abdomen, lower limb, small muscles of toes and fingers. Some of the conditions simulating Rigor mortis are Cadaveric spasm or instantaneous rigor, Heat stiffening, Cold stiffening, Gas stiffening.

Late changes after death- (1) Decomposition/putrefaction- it is the process by which complex organic body tissues breaks down into simpler inorganic compounds or elements due to action of saprophytic microorganisms or due to autolysis. The important features are discolouration of lower abdominal quadrants, distensions due to gases accumulation, degradation due to loss of integrity of skin and other tissues such as peeling of skin (skin slippage), loosening of skin of hands and feet (degloving), loosening of hair and nails, dissolution characterized by liquefaction and disappearance of tissues and organs, and eventual skeletonization. Marbling of skin and postmortem luniniscence are other important changes. The organs composed of muscular tissue and those containing large amount of fibrous tissue resist decomposition longer than the parenchymatous organs with the exception of stomach and intestine, which decompose rapidly because of their contents at the time of death. (2) Adipocere / saponification - It is formation of sweet rancid smelling, soft, whitish or greyish white, waxy, greasy and crumby material ocurring in fatty tissues of a dead body. It hot and moist environment, it may occur by the end of one week.in temperate climate, it may take between three weeks to three months period. (3) Mummification It is the rapid dehydration and shrivelling of the dead body from evaporation of water, with the preservation of natural appearances and features of the body. The entire body becomes thin, stiff, brittle and odourless. Time required for mummification varies from three to twelve months period or even longer.

Diagnosing death after it has reached the cellular or molecular stage with the obvious early and late changes is not a matter of question. Diagnosing death at the somatic stage taking into consideration of the immediate body changes requires expertise. Death is diagnosed using the most appropriate criteria for the circumstances in which a medical practitioner may be called upon. Three sets of criteria are somatic criteria, circulatory criteria and neurological criteria. All can be 
used to demonstrate the irreversible loss of the capacity for consciousness combined with the irreversible loss of the capacity to breathe. In the community and where death may have occurred hours to days before, somatic criteria will reliably indicate the loss of these two essential capacities. When death is more recent and especially within a hospital setting, death is usually diagnosed by the use of circulatory criteria after cardiorespiratory arrest. It is only within the critical care environment, where mechanical ventilation is used, that the diagnosis of death using neurological criteria is applied. [15]

\subsection{Evolution of the Concept of Brain Death}

Prior to 1960, death was defined as the complete and irreversible cessation of spontaneous cardiac and respiratory functions. In 1968, the concept of Brain Death came forward after the publication of the landmark report, "the definition of irreversible coma." by an Ad Hoc Committee of Harvard Medical School on Brain Death. [16] The purpose of the Harvard criteria was avoidance of prolonged futile life-support and promoting death with dignity. After this report, brain death was widely accepted. [17] The Harvard criteria included - 1) Deep coma / no withdrawal to painful stimuli. 2) arreflexia. 3) Apnoea. 4) Flat electrocephalogram (EEG) 5) Exclusion of hypothermia and drugs. 6) Above evaluations to be repeated in 24 hours. [18]

In 1971, Mohandas and Chou emphasized the importance of irreversible loss of brain-stem function in brain death (Minnesota criteria). [19] The Minnesota criteria was similar to The Harvard criteria except EEG was omitted, re-examination to be done after 12 hours and ventilator discontinuation for 4 minutes rather than 3 minutes and the mandatory criteria that the patient should have irrefutable intracranial lesion along with the sign of brain death. [20]

In 1976, the Conference of Medical Royal Colleges in the UK published a breakthrough code for the determination of "brain death" (brain-stem death) based on the brain stem functions. [21] The code requires confirmation of the "irreversible loss of the capacity for consciousness combined with the irreversible loss of the capacity to breathe." The brain-stem death concept is based on arguments that asystole inevitably follows the diagnosis and that cognitive processing is incompatible with death of the midbrain. [22] In the UK, Pallis championed the concept of brainstem death, pointing out that the accepted clinical tests all assessed brainstem function, that the brainstem was responsible for consciousness, breathing and circulatory regulation, and that it conducted nearly all throughput to and from the brain. [23] This criteria eliminated the need for re-examination and mandated specific level $\mathrm{CO}_{2}$, rather than simply time to determine the result of Apnoea test. [24]

The U.S. collaborative study re-introduced a flat EEG and repeat exam (30-60 mints) but dropped the apnoea test and added absent cerebral circulation as optional test. [25]

In 1981, the US President's Commission published a landmark report on the ethical and legal implications of defining death and presented conceptual basis for whole-brain-death. [26] It evaluated non-brain (circulatory) formulation, whole-brain formulation and higher brain formulation of death and approved the whole-brain formulation. The report defined death as: "The permanent cessation of functioning of the organism as a whole" and the criterion as: "The permanent cessation of functioning of the entire brain." The commission's concept of brain death 
rested on the claims that brain is the source of integration for the organism as a whole and brain death is consistent with the traditional cardiopulmonary criterion. Consistency is maintained with supposed fact that after brain-death, cardiopulmonary death quickly follows despite continued intensive care. This is known as the somatic disintegration hypothesis. The commission's report leads to the Uniform Determination of Death Act [27] according to which, "an individual who has sustained either (1) irreversible cessation of circulatory and respiratory functions or (2) irreversible cessation of all functions of the entire brain, including the brain-stem, is dead. A determination of death must be made in accordance with accepted medical standards." It does not mention what are accepted medical standards. [28] This criteria brought back the apnoea test and required a repeat exam and cerebral flow determination as optional criteria. [29]

India follows the UK system of Brain- stem Death criteria. [30] However, the general awareness regarding the concept of Brain Death, Brain-stem death, procedure for organ donation and the legal implication involved is still very low in India. [31] The Transplantation of human Organs (THO) Act was passed in 1994 and later amendment done in 2011. This act legalised the Brain-stem Death in India. Brain-stem Death means the stage at which all functions of the brain stem have permanently and irreversibly ceased. Deceased person means a person in whom permanent disappearance of all evidence of life occurs, by reason of brain-stem death or in a cardio-pulmonary sense, at any time after live birth has taken place. [32, 33]

THO Rules were laid down in 1995 which describes brain death certification procedure. [34, 35] The THO Act 1994 was enacted at the request of the states of Maharastra (India), Goa (India) and Himachal Pradesh (India). So these states adopted it by default and other states also adopted subsequently except Andhra Pradesh and Jammu and Kashmir (India).[36] The state of Maharastra has made it mandatory for all the Authorized Transplant centres and the hospitals registered as Non-Transplant Organ Retrieval Centres (NTORCs) to certify and notify the brain death cases to zonal transplantation co-ordination committee. Form 8 of THO Act and Rules prescribed as BrainDeath Certification format is to be utilized to certify brain-stem death. [37] Team of four medical experts includes Medical Administrator In charge of the hospital, Authorized Specialist, Authorized Neurologist/Neuro-Surgeon and Medical Officer treating the patient. Amendment of THO act in 2011 has allowed selection of surgeon/physician/ and an anaesthetist / intensivist in the event of unavailability of approved neuro-surgeon. [38] Transplantation of Human organs and tissue Rules (2014) gives direction about the panel of experts for brain-death certification.[39]

\subsection{Criteria for Diagnosis of Brain-Stem Death in India [40]}

1) Patient should be deeply comatose due to irreversible brain damage of known etiology and reversible causes of coma excluded.

2) Patient should be on a ventilator because of the cessation of spontaneous respiration and neuromuscular blocking agents as a cause of respiratory failure excluded.

3) All brain-stem reflexes should be absent:

- Pupillary light reflex - Pupils dilated, fixed and not reacting to light.

- Doll's head eye movements (oculocephalic reflex) (absence of conjugate deviation of eyes when head is fully rotated to one side. Performed only when there is no fracture or instability of the cervical spine.

- Corneal reflex is absent. 
- No motor response to stimulation within any cranial nerve distribution (e.g. no response to the supraorbital pressure).

- No Gag (Pharyngeal) reflex (to stimulation of pharynx).

- No Cough reflex (to suction catheter in the trachea).

- Vestibulo-occular reflex (oculovestibular reflex/ caloric testing) absent (No eye movements after installation of $50 \mathrm{ml}$ of ice cold water into each external acoustic meatus for $1 \mathrm{~min})$.

- Apnoea test (absence of respiratory movements after disconnection from the ventilator for sufficient duration to have pCO2 rise above threshold $(>50-60 \mathrm{mmHg}$ ) for stimulating respiration) All the prescribed tests are required to be repeated, after minimum interval of $6 \mathrm{~h}$, "to ensure that there has been no observer error" and persistence of the clinical state can be documented.

\section{Discussion}

The criteria for diagnosis of death have evolved over the years and in part of the world. Techniques used in one region and one era may differ from the other. However, the aim was always to ascertain the cessation of the function of the three pillars of life i.e. brain, heart and lungs. The common techniques mentioned in Ayurveda textbooks like using strong collyrium and insufflation to arouse the patients, meant to check for the irreversibility of unconsciousness, to decide about the cessation of the function of brain and lungs. Similarly, absence of bleeding on incision indicated the circulatory failure. The failure to develop linear marks on body parts when hit by baton indicates flaccidity of muscles and skin. Failure to develop horripilation on stimulus indicates insensibility. Similarly, coated tongue, plucking off of hairs, dislocation of joints fixed jaw, absence of movement of eyeball, permanent and fixed opening of anus, mouth and eyes indicates early and late signs of death, which are also explained in modern textbooks under the various headings like changes in eyes, muscle changes, rigor mortis, putrefaction etc.

The complete and irreversible cessation of the function of the brain, heart and lung were considered as the sign of death initially. However, with the advancement in technology and development of artificial ventilator system especially, the onus is on brain death. Even in brain death, brain stem death is on focus. The possibility for transplantation of organ have played a major role in the changes and variation in the criteria for declaring death.

\section{Conclusion}

Declaring death is not just a medical decision, one has to take account of all the circumstances which makes it a very delicate decision with no room for error. Criteria for diagnosis of death have evolved, still no single universally accepted criteria exists. But the onus is always on the three vital organs- brain, heart and lungs. Ayurveda treatises mentions different techniques used in different era and different regions of India. These criteria also focussed on declaring death based on the cessation of the function of the three vital organs, although using different sets of techniques. Better, more specific and accurate techniques have evolved over the years, but, to have a standard and scientific criteria for declaring death thousands of years back, speaks volume and quality of the Ayurveda literature. 


\section{References}

[1] Shemie SD, Hornby L, Baker A, Teitelbaum J, Torrance S, Young K, Capron AM, Bernat JL, Noel L. International guideline development for the determination of death. Intensive care medicine. 2014 Jun 1;40(6):788-97.

[2] Biswas, G. Review of Forensic Medicine and Toxicology. (3rd ed.). New Delhi: Jaypee Brothers Medical Publishers; 2015.

[3] Gardiner D, Shemie S, Manara A, Opdam H. International perspective on the diagnosis of death. British Journal of Anaesthesia. 2012 Jan 1;108:i14-28.

[4] Morison RS. Death: Process or event. Science. 1971 Aug 20;173(3998):694-8.

[5] Gardiner D, Shemie S, Manara A, Opdam H. International perspective on the diagnosis of death. British Journal of Anaesthesia. 2012 Jan 1;108:114-28.

[6] Narayanaswamy V. Origin and development of ayurveda:(a brief history). Ancient science of life. $1981 \mathrm{Jul} ; 1(1): 1$.

[7] Agnivesa. Visha chikitsa 23/33-34. In: Charaka, Dridhavala, Trikamji, V.J (eds.) Charaka Samhita. Varanasi (India): Chaukahambha Orientalia; 2015. p. 573.

[8] Narayanaswamy V. Origin and development of ayurveda:(a brief history). Ancient science of life. $1981 \mathrm{Jul} ; 1(1): 1$.

[9] Susruta. Kalpa sthana 3/40-41. In: Trikamji, V.J (ed.) Susruta Samhita. Varanasi (India): Chaukahambha Orientalia; 2014. p. 570.

[10] Narayanaswamy V. Origin and development of ayurveda:(a brief history). Ancient science of life. $1981 \mathrm{Jul} ; 1(1): 1$.

[11] Vagbhata. uttarasthana 36/36. In: Harisastri, V.P (ed.) ASTANGAHRIDAYAYAM. Varanasi (India): Chaukahambha Orientalia; 2014. p. 910.

[12] Namboodiri, C.K. Vishavaidyasarasamuchaya. (1st ed.). Thrissur (India): Ullannoor Mana Trust; 2006.

[13] Mahadevasastrikal, K. Visha vaidya jyotsnika - an english translation. (3rd ed.) Trivandrum (India): Government of His Highness the Maharaja of Travancore; 1958.

[14] Biswas, G. Review of Forensic Medicine and Toxicology. (3rd ed.). New Delhi: Jaypee Brothers Medical Publishers; 2015.

[15] Gardiner D, Shemie S, Manara A, Opdam H. International perspective on the diagnosis of death. British Journal of Anaesthesia. 2012 Jan 1;108:i14-28.

[16] Beecher HK. Report of the ad hoc committee of the Harvard Medical School to examine the definition of brain death: The definition of irreversible coma. Transplantation. 1969 Mar 1; 7(3):204.

[17] Dhanwate AD. Brainstem death: A comprehensive review in Indian perspective. Indian journal of critical care medicine: peer-reviewed, official publication of Indian Society of Critical Care Medicine. 2014 Sep; 18(9):596.

[18] Daroff RB. The historical evolution of brain death from former definitions of death: Harvard criteria to present. The Signs of Death. Scripta Varia. 2006; 110:217-.

[19] Mohandas A, Chou SN. Brain death: a clinical and pathological study. Journal of neurosurgery. 1971 Aug; 35(2):211-8.

[20] Daroff RB. The historical evolution of brain death from former definitions of death: Harvard criteria to present. The Signs of Death. Scripta Varia. 2006; 110:217-.

[21] Korein J. The diagnosis of brain death. InSeminars in neurology 1984 Mar (Vol. 4, No. 01, pp. 5272). (C) 1984 by Thieme Medical Publishers, Inc.

[22] Dhanwate AD. Brainstem death: A comprehensive review in Indian perspective. Indian journal of critical care medicine: peer-reviewed, official publication of Indian Society of Critical Care Medicine. 2014 Sep; 18(9):596.

[23] Pallis C. ABC of brain stem death. The position in the USA and elsewhere. British medical journal (Clinical research ed.). 1983 Jan 15; 286(6360):209. 
[24] Daroff RB. The historical evolution of brain death from former definitions of death: Harvard criteria to present. The Signs of Death. Scripta Varia. 2006; 110:217-.

[25] Daroff RB. The historical evolution of brain death from former definitions of death: Harvard criteria to present. The Signs of Death. Scripta Varia. 2006; 110:217-.

[26] Dhanwate AD. Brainstem death: A comprehensive review in Indian perspective. Indian journal of critical care medicine: peer-reviewed, official publication of Indian Society of Critical Care Medicine. 2014 Sep; 18(9):596.

[27] Dhanwate AD. Brainstem death: A comprehensive review in Indian perspective. Indian journal of critical care medicine: peer-reviewed, official publication of Indian Society of Critical Care Medicine. 2014 Sep; 18(9):596.

[28] Dhanwate AD. Brainstem death: A comprehensive review in Indian perspective. Indian journal of critical care medicine: peer-reviewed, official publication of Indian Society of Critical Care Medicine. 2014 Sep; 18(9):596.

[29] Daroff RB. The historical evolution of brain death from former definitions of death: Harvard criteria to present. The Signs of Death. Scripta Varia. 2006; 110:217.

[30] Dhanwate AD. Brainstem death: A comprehensive review in Indian perspective. Indian journal of critical care medicine: peer-reviewed, official publication of Indian Society of Critical Care Medicine. 2014 Sep;18(9):596.

[31] Wig N, Gupta P, Kailash S. Awareness of brain death and organ transplantation among select Indian population. JOURNAL-ASSOCIATION OF PHYSICIANS OF INDIA. 2003 May 17; 51:455-8.

[32] Government of India. Ministry of Law, Justice and CompanyAffairs (Legislative Department) New Delhi. The Transplantation of Human Organs Act, 1994. Central Act 42 of 1994. Available from: http://www.health.bih.nic.in/Rules/THOA-1994.pdf. [Last accessed on 2018 MAY 1].

[33] Mohanfoundationorg. Mohanfoundationorg. [Online]. Available from: http://www.mohanfoundation.org/THO-amendment-act-2011.pdf. [Accessed 31 May 2018].

[34] Googlecoin. Googlecoin. [Online]. Available from: https://www.google.co.in/search?ei=EdAPW6WbEZO6vwSXqZ_oDw [Accessed 31 May 2018].

[35] Government of India. Ministry of Law, Justice and Company Affairs (Legislative Department) New Delhi. Transplantation of Human Organs (Amendment) Rules, 2008. Available from: http://www.health.bih.nic.in/Rules/THO-A-Rules-2008.pdf. [Accessed 31 May 2018].

[36] Organindiaorg. Organindiaorg. [Online]. Available from: http://organindia.org/wp-content/uploads/2014/10/1.THOA-ACT-1994.pdf [Accessed 5 June 2018].

[37] Organindiaorg. Organindiaorg. [Online]. Available from: http://organindia.org/wp-content/uploads/2014/10/2.THO-Rules-1995-Original-Rules.pdf [Accessed 5 June 2018].

[38] Organindiaorg. Organindiaorg. [Online]. Available from: http://www.organindia.org/wp-content/uploads/2014/10/4.THOA-amended-ACT-2011.pdf [Accessed 5 June 2018].

[39] Organindiaorg. Organindiaorg. [Online]. Available from: http://www.organindia.org/wp-content/uploads/2014/10/5.THOA-Rules-2014.pdf [Accessed 5 June 2018].

[40] Organindiaorg. Organindiaorg. [Online]. Available from: http://www.organindia.org/wp-content/uploads/2014/10/5.THOA-Rules-2014.pdf [Accessed 5 June 2018]

*Corresponding author.

E-mail address: gopendra2014@ gmail.com 